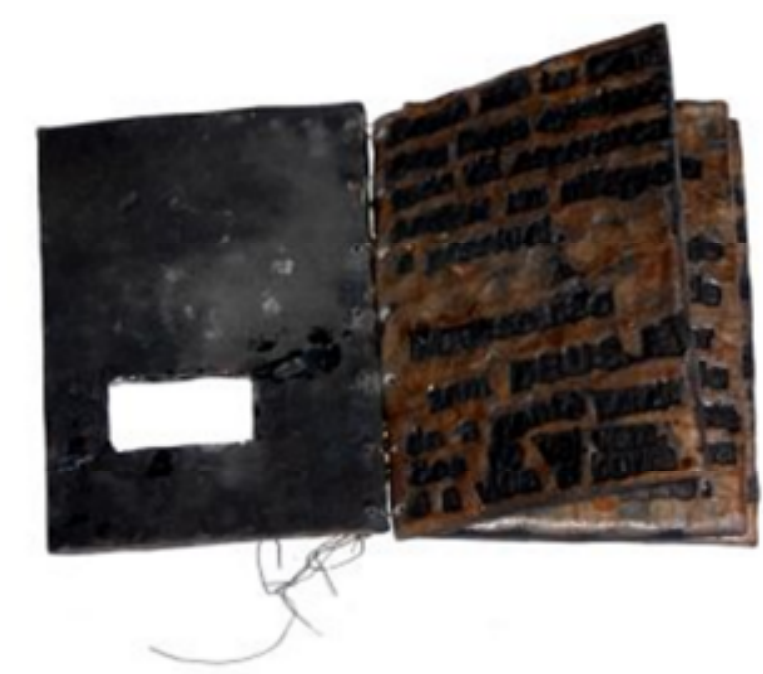

\title{
GRAPHOS - a escrita da memória-imagem de Grande sertão: veredas
}

\section{Wanêssa Cristina Vieira Cruz}

Wanêssa Cristina Vieira Cruz é escultora e ceramista, graduada em Artes Plásticas e Pós-graduada em Arte e Contemporaneidade pela Escola Guignard/UEMG. Mestranda FALE/UFMG 2007.

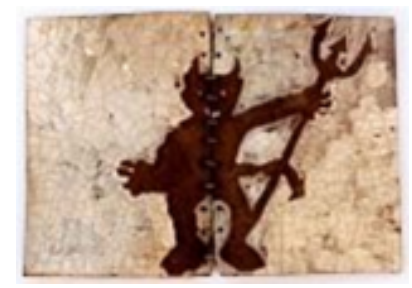

Essa produção plástica - livros-objeto em cerâmica, insere-se no que Mirella Bentivoglio denominou "librismo" - termo que caracteriza a tendência para se escolher o livro como espaço de todo tipo de manifestação. Ao apropriar-me do "livro", fiz com que ele simultaneamente fosse receptáculo de sabedoria e cultura.

O barro, como literatura a ser lida, antecipa um livro. A letra e o desenho grafam, ao narrar a memória do vivido. Os atos de arranhar, imprimir, marcar graphos - sobre a superfície do barro dentro do texto roseano solicitam o leitor pelas imagens que se desdobram, construindo 

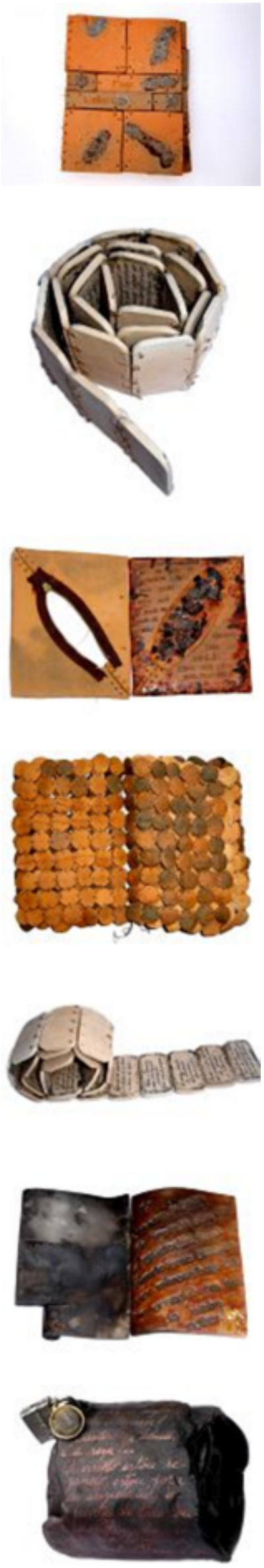

outros signos/ícones, num exercício de produção de sentidos.

- traço sobre o barro é o corpo que arranha, que marca, a partir da noção de graphos enquanto inscrição de signos. A escrita tipográfica é o grafo de uma prática, a de imprimir, revelando o contraste do baixo-relevo com a planura da página em argila. Gesto manual, registro de marcas. Qualquer inscrição no barro tornase lugar de memórias.

A cerâmica, em sua relação com a impressão, incorpora e retém em sua matéria a memória de sua feitura, de um tempo atuado. A textura representa a memória do gesto e as impressões presentificam resquícios desse tempo passado.

A série livros-objeto realiza a ambição de produzir objetos sensórios. Somos solicitados em quase todos os sentidos ao manipulá-los: a visão é o primeiro e essencial sentido exigido, mas o desdobramento visual a partir do repertório de materiais agregados que se relacionam diretamente com o sentido da obra nos impele ao tato. Há uma riqueza assombrosa de sensações táteis nesses livros: palavras, texturas, fios, a transparência do vidro, a opacidade do pó de latão, o chumbo fundido, o contraste do rústico com - acetinado do esmalte em diferentes técnicas. Isso estabelece uma conexão com o auditivo, ao manipularmos sucessivamente suas páginas sonoras.

A estrutura do livro passa a ser capturada pela estrutura plástica: narrativa literária e narrativa plástica convivem harmoniosamente. Na construção dos livrosobjeto, vários aspectos são explorados plasticamente como o fato de que um livro proporciona prazer intelectual por meio de seu texto, mas também prazer tátil e visual.

O limite preciso entre o visual e o literário se dilui cada vez mais, tornando clara a combinação das diversas linguagens 

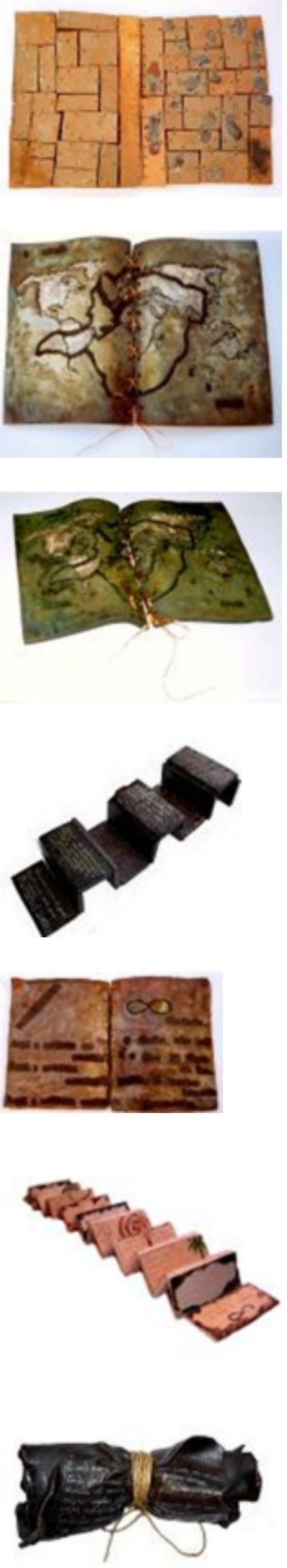

artísticas: desenho, pintura, escritura e escultura. A escrita, ao dialogar com a visualidade, reafirma a grande tendência das artes visuais a partir do séc. XX: integrar a palavra ao discurso plástico, recurso que propicia ao texto interferir no interior mesmo da imagem, funcionando também como imagem.

Da argila úmida trabalhada pelos mesopotâmicos aos meios hoje conhecidos da escrita, há um espetáculo de transformações e invenções. A evolução das máquinas e dos computadores não apagou, pelo contrário, valorizou ainda mais, o documento único e antigo, peça rara e aurática. É nesse patamar que o livro-objeto de cerâmica se sobressai, pois traz o caráter do irrepetível, do instante com a aura do eterno. A palavra inscrita sobre a argila quebra o caráter passageiro da mensagem; registra e reorganiza o transitório.

Desde sua origem, por meio de suportes como tabletes de argila e nas diversas formas de escrita, os homens utilizaram-se desse artifício para produzir memória. No texto e na memória, atua um sujeito que seleciona, recorta e constrói uma história dotada de sentido. "GRAPHOS - a escrita da memóriaimagem de Grande sertão: veredas" revela que toda imagem acaba por produzir inúmeros textos que se inscrevem aqui como uma transcriação intersemiótica. Textura que se dá como um híbrido de texto, tecido e leitura: uma forma de se ver textos de arte. 